\title{
Isolation of Lasiodiplodin and Evaluation of some Biological Activities of the Stem Barks of Phyllanthus Albizzioides (Kurz) Hook.f.
}

\author{
Khine Zar Wynn Lae ${ }^{a^{*}}$, Su Swe Su ${ }^{\text {a }}$, Nwet Nwet Win ${ }^{\text {b }}$, Ni Ni Than ${ }^{\text {a }}$, Hla Ngwe ${ }^{\text {a }}$ \\ ${ }^{a}$ Department of Chemistry, University of Yangon, Yangon, 11041, Myanmar. \\ ${ }^{b}$ Institute of Natural Medicine, University of Toyama, 2630-Sugitani, Toyama 930-0194, Japan.
}

Received 02 September 2019; Accepted 22 November 2019

\begin{abstract}
A large number of the plants are claimed to possess the antibiotic properties in the traditional system and are also used extensively by the tribal people throughout the world. It is now mostly thought that nature has given the cure of every disease in one form or another. Plants have been known to cure people from various diseases in Ayurveda. This research focused on the screening of phytochemicals and some biological activities of Phyllanthus albizzioides. The research showed that the ethanol extracts were found to be greater chemical constituents than watery extracts. Among the chemical constituents, steroid compounds were observed in highest amount in ethanol extract and the second highest in flavonoid compounds followed by tannin compounds and pheolic compounds. Furthermore, the ethanol extracts were more effective than the watery extracts in all tested biological activities such as antioxidant, anti-diabetic, cytotoxicity, antimicrobial, antitumor and NO inhibition activities. A cyclohexanone compound was isolated from the chloroform extract of the stem bark of $P$. albizzioides. The relative structure was determined to be 4,5-dihydroxy-3-methyl-cyclohex-2-enone on the basic of HRESIMS, ${ }^{1} \mathrm{H}$ NMR and ${ }^{13} \mathrm{C}$ NMR spectroscopic analyses, including 2D NMR experiments.
\end{abstract}

Keywords: Phyllanthus Albizzioides; Phytochemicals; Nutritional Values; Antioxidant Activity; Modern Spectroscopic Techniques.

\section{Introduction}

In spite of great advances of modern scientific medicine, traditional medicine is still the primary form of treating diseases of majority of people in developing countries including Myanmar; even among those to whom Western medicine is available, the number of people using one form or another of complementary of alternative medicine is rapidly increasing worldwide [1]. Over the centuries, humans have relied on plants for basic needs such as food, clothing, and shelter, all produced or manufactured from plant matrices (leaves, woods, fibers) and storage parts (fruits, tubers) [2]. Many plant-derived compounds have been used as drugs, either in their original or semi-synthetic form [3]. The World health Organization (WHO) estimates that about $80 \%$ of the population living in the developing countries relies almost exclusively on traditional medicine for their primary healthcare needs [4]. Myanmar is the largest producer of medicinal herbs and is appropriately called the botanical garden of the world.The plants that possess therapeutic properties or exert beneficialpharmacological effects on the animal and human body are generally designatedas medicinal plants. The history of the use of medicinal plants for alleviating diseases had its origin in the activities of the most primitive man of the remote past. Medicinal plants constitute an important natural wealth of a country. They play a significant role in providing primary health care services to rural people. They serve as important therapeutic agents as well as important raw materials for the manufacture of traditional and modern medicines. They are rich sources of bioactive compounds and thus serve as important rawmaterials for drug production. They constitute

* Corresponding author: kzwlae@gmail.com

\section{doi http://dx.doi.org/10.28991/SciMedJ-2019-0104-5}

$>$ This is an open access article under the CC-BY license (https://creativecommons.org/licenses/by/4.0/).

(C) Authors retain all copyrights. 
a precious natural wealth of a country and contribute a great deal to its health care programs. Judicious and scientific exploration of this wealth can significantly improve the general health of the people [5]. According to traditional beliefs in Myanmar, there are 96 diseases that afflict humans. Myanmar traditional knowledge and medicine is believed to be able to cure all of these diseases by using ingredients such as fresh or dried roots, stems, leaves, buds, and flowers. With its beginnings in similar traditional medicine systems of neighboring countries, traditional medicine in Myanmar has been enriched by traditions, adaptations, and adoptions of different practices throughout the centuries. Traditional medicine continues to be widely practiced by the majority of the population, partly as a supplement and partly as an alternative to modern medicine.

In this research work, one Myanmar medicinal plant was collected namely, $P$. albizzioides. $P$. albizzioides is in the family of Euphorbiaceae. On the basic of preliminary isocratic TLC experiments, P. albizzioides was selected to fractionate using the solvent mixture of petroleum ether, chloroform, acetone and methanol.

\section{Materials and Methods}

\subsection{Plant Materials}

In the present work, the barks of $P$. albizzioides was chosen as sample to be studied. The barks of $P$. albizzioides were collected from Meikhtila Division, Mandalay Region, Myanmar. The dried powder samples were used for chemical and biological investigations.

\subsection{Phytochemical Screening}

The dried powdered samples were subjected to preliminary phytochemical tests in order to screen the types of phytoorganic constituents present in the sample. Preliminary phytochemical tests on the sample were carried out according to the appropriate reported methods.

\section{(1) Test for alkaloids}

Dried powdered sample (5 g) was boiled with $1 \%$ hydrochloric acid $(50 \mathrm{~mL})$ for about 10 minutes and filtered after cooling. The filtrate was divided into three portions and tested with Mayer's reagent, Dragendorff's reagent and Wagner's reagent. The following observations were made whether alkaloids were present or not. When the first portion of the filtrate was treated with a few drops of Mayer's reagent, white precipitate was formed, that indicated the presence of alkaloids. When a few drops of Dragendorff's reagent were added to the second portion of the filtrate, orange precipitate was formed, that indicated the presence of alkaloids. Finally, when a few drops of Wagner's reagent were added to the third portions of the filtrate, reddish brown precipitate was formed, that indicated the presence of alkaloids $[6,7]$.

(2) Test for $\alpha$-amino acids

Dried powdered sample ( $2 \mathrm{~g}$ ) was boiled with distilled water $(20 \mathrm{~mL})$ for about 10 minutes and then filtered. An aliquot portion of filtrate was transferred to a filter paper by capillary action and was sprayed with ninhydrin reagent and allowed to dry at $100{ }^{\circ} \mathrm{C}$ on an oven for about 5 minutes. Pink or violet coloured spot indicated the presence of $\alpha$ amino acids [8].

\section{(3) Test for carbohydrates}

Dried powdered sample $(2 \mathrm{~g})$ was boiled with distilled water $(20 \mathrm{~mL})$ for about 20 minutes and then filtered. The filtrate was placed into a test tube and a few drops of $10 \% \alpha$-naphthol was added and then shaken. This test tube was inclined at an angle of $45^{\circ}$ and concentrated sulphuric acid $(1 \mathrm{~mL})$ was slowly added along the inner side of the test tube. The red ring was formed between the two layers indicating the presence of carbohydrates [9].

\section{(4) Test for cyanogenic glycosides}

Dried powdered sample ( $2 \mathrm{~g})$ was mixed with distilled water in conical flask. About 5 drops of concentrated sulphuric acid was added and sodium picrate paper was trapped in a neck by means of a cork. The resulting mixture was heated by means of a spirit burner. Brick red colour indicated the presence of cyanogenic glycosides [6].

(5) Test for flavonoids

Dried powdered sample $(1 \mathrm{~g})$ was refluxed with ethanol $(25 \mathrm{~mL})$ and then filtered. Concentrated hydrochloric acid $(2 \mathrm{~mL})$ and a few piece of magnesium turning were added to the ethanol extract. The mixture turns pink colour within three minutes indicating the presence of flavonoids [2].

(6) Test for glycosides

Dried powdered sample ( $2 \mathrm{~g})$ was boiled with distilled water $(25 \mathrm{~mL})$ for about 10 minutes and then filtered after cooling. The filtrate was tested with $10 \%$ lead acetate solution. Formation of white precipitates indicated the presence 
of glycosides [8].

(7) Test for organic acids

Dried powdered sample $(1 \mathrm{~g})$ was extracted with distilled water $(5 \mathrm{~mL})$ and treated with a few drop of bromocresol green indicator. The dark green colour was formed indicating the presence of organic acids [7].

(8) Test for phenolic compounds

Dried powdered sample ( $2 \mathrm{~g})$ was boiled with distilled water $(20 \mathrm{~mL})$ for about 10 minutes and then filtered. The filtrate was treated with three drops of freshly prepared $1 \%$ potassium ferricyanide and $1 \%$ ferric chloride solution. The solution gives dark green colour indicated the presence of phenolic compounds [9].

(9) Test for reducing sugars

Dried powdered sample $(2 \mathrm{~g})$ was boiled with distilled water $(25 \mathrm{~mL})$ for about 10 minutes and then filtered after cooling. The filtrate was tested with a mixture of Fehling's solutions A and B in equal volume and boiled for 10 min in boiling water bath. Brick red precipitates indicated the presence of reducing sugars [10].

(10) Test for saponins

Dried powdered sample $(1 \mathrm{~g})$ was put into a test tube followed by the addition of distilled water and the mixture was vigorously shaken for a few minutes. Formation of froth indicated the presence of saponins [11].

(11) Test for starch

Dried powdered sample $(1 \mathrm{~g})$ was extracted with distilled water $(5 \mathrm{~mL})$ and the extract was treated with a few drops of freshly prepared $1 \%$ iodine solution. The blue colour indicated the presence of starch [7].

(12) Test for steroids

Dried powdered sample $(2 \mathrm{~g})$ was extracted with petroleum ether $(25 \mathrm{~mL})$ for 30 minutes and filtered. The filtrate solution was added with acetic anhydride $(2 \mathrm{~mL})$ followed by concentrated sulphuric acid $(1 \mathrm{~mL})$. Observation was made to see if the solution turned to blue or greenish blue colour, indicating the presence of steroid [8].

\section{(13) Test for tannins}

Dried powdered sample ( $2 \mathrm{~g}$ ) was individually boiled with distilled water and then filtered. The filtrate was treated with $1 \%$ gelatin solution. Formation of white precipitates indicated the presence of tannins [11].

(14) Test for terpenoids

The powdered sample $(2 \mathrm{~g})$ was extracted with hot chloroform $(20 \mathrm{~mL})$ for 30 minutes and filtered. The filtrate was treated with a few drops of acetic anhydride and concentrated sulphuric acid. Red or pink colouration indicated the presence of terpenoids [9].

\subsection{Quantitative Determination of Phytochemical Constituents}

(1) Determination of total steroid contents of the samples by Zak's method

Firstly, the stock ferric chloride solution was prepared by dissolving $84 \mathrm{mg}$ of pure ferric chloride in $10 \mathrm{~mL}$ of glacial acetic acid. Ferric chloride diluting reagent was prepared by $8.5 \mathrm{~mL}$ of stock ferric chloride solution was diluted to $100 \mathrm{~mL}$ with pure glacial acetic acid. The watery and EtOH extracts were prepared according to the procedure. Each crude extract $(1 \mathrm{mg})$ was dissolved in $10 \mathrm{~mL}$ of ferric chloride diluting reagent to get the sample solution at concentration of $100 \mu \mathrm{g} / \mathrm{mL}$. The stock solution of standard cholesterol was prepared by dissolving $1 \mathrm{mg}$ of cholesterol in $20 \mathrm{~mL}$ of ferric chloride diluting reagent. The stock solution was twofold diluted serially with ferric chloride diluting reagentto get the standard cholesterol solutions with the different concentrations of 50, 25, 12.5 and $6.25 \mu \mathrm{g} / \mathrm{mL}$. In this experiment, $2.5 \mathrm{~mL}$ of each of different concentrations of cholesterol solution was mixed with $2.5 \mathrm{~mL}$ of concentrated sulphuric acid. The resultant mixture was allowed to stand for 30 minutes at room temperature. Absorbance of the resulting red colour solution was measured against reagent blank at $540 \mathrm{~nm}$ by using UV spectrophotometer (KWG UV-7504). All samples were measured in triplicate. A standard curve was prepared by plotting the absorbance against concentrations of cholesterol. This standard curve of cholesterol solutions (range from $6.25 \mu \mathrm{g} / \mathrm{mL}$ to $50 \mu \mathrm{g} / \mathrm{mL}$ ) was used for calibration. The steroid content in each sample was estimated by Zak's method. Extract solution $(2.5 \mathrm{~mL})$ was mixed with $2.5 \mathrm{~mL}$ of concentrated sulphuric acid. The resultant mixture was allowed to stand for 30 minutesat room temperature. Absorbance of the resulting blue solution was measured against reagent blank at $540 \mathrm{~nm}$ using spectrophotometer (KW UV-7504). The experiment was done in triplicate. Results were expressed as miligram of cholesterolequivalents (CE) per gram of extract (CE mg/g dry extract). The concentrations of cholesterol equivalent $(\mathrm{QE})$ in the plant extracts were calculated by using the linear regressive 
equation from standard calibration curve of cholesterol. Steroid contents in the plant samples were expressed as mg cholesterolequivalent per $1 \mathrm{~g}$ dry plant extract [12].

(2) Determination of total flavonoid contents of the samples by aluminium chloride colorimetric (ACC) method

The total flavonoid contents (TFCs) of the samples were determined UV- spectrometrically according to aluminum chloride colorimetric method [13]. Firstly, $0.5 \mathrm{~mL}$ of each of different concentrations of quercetin solution was mixed with $1.5 \mathrm{~mL}$ of methanol, $0.1 \mathrm{~mL}$ of $1 \%$ aluminiun chloride solution and $0.1 \mathrm{~mL}$ of $1 \mathrm{M}$ potassium acetate and $2.8 \mathrm{~mL}$ of distilled water. The resultant mixture was allowed to stand for 30 minutes at room temperature. Absorbance of the resulting pale yellow solution was measured against reagent blank at $415 \mathrm{~nm}$ by using UV spectrophotometer (KWG UV-7504). All samples were measured in triplicate. A standard curve was prepared by plotting the absorbance against concentrations of quercetin. This standard curve of quercetin solutions (range from $1.25 \mu \mathrm{g} / \mathrm{mL}$ to $20 \mu \mathrm{g} / \mathrm{mL}$ ) was used for calibration. The total flavonoid content in each sample was estimated by Aluminum Chloride Colorimetric Assay. Each extract $(20 \mathrm{mg})$ was mixed with $20 \mathrm{~mL}$ of distilled water.Each of this extract solution $(0.5 \mathrm{~mL})$ was mixed with $1.5 \mathrm{~mL}$ of methanol, $0.1 \mathrm{~mL}$ of $1 \%$ aluminiun chloride solution, $0.1 \mathrm{~mL}$ of $1 \mathrm{M}$ potassium ace tate and 2.8 $\mathrm{mL}$ of distilled water. The resultant mixture was allowed to stand for 30 minutes at room temperature. Absorbance of the resulting pale yellow solution was measured against reagent blank at $415 \mathrm{~nm}$ by using spectrophotometer (KWF UV-7504). The experiment was done in triplicate. Results were expressed as miligram of quercetin equivalents (QE) per gram of extract ( $\mathrm{QE} \mathrm{mg/g} \mathrm{dry} \mathrm{extract).} \mathrm{The} \mathrm{concentrations} \mathrm{of} \mathrm{quercetin} \mathrm{equivalent}(\mathrm{QE})$ in the plant extracts were calculated by using the linear regressive equation from standard calibration curve of quercetin. Total flavonoid contents (TFC) in the plant sample was expressed as mg quercetin equivalent per $1 \mathrm{~g}$ dry plant extract(mg QE/g extract).

\section{(3) Determination of total condensed tannin content of the samples by Broadhurst method}

The total tannin contentsof the samples were determined UV- spectrometrically according to Broadhurst method [14]. In this experiment, $0.4 \mathrm{~mL}$ of each of different concentrations of tannic acidsolution was mixed with $3 \mathrm{~mL}$ of 4 $\%$ vanillin and $1.5 \mathrm{~mL}$ of concentrated hydrochloric acid. The resultant mixture was incubated for 15 minutes in the incubator. Absorbance of the resulting blue solution was measured against reagent blank at $500 \mathrm{~nm}$ by using UV spectrophotometer (KWG UV-7504). All samples were measured in triplicate. A standard curve was prepared by plotting the absorbance against concentrations of tannic acid. This standard curve of tannic acid solutions (range from $6.25 \mu \mathrm{g} / \mathrm{mL}$ to $50 \mu \mathrm{g} / \mathrm{mL}$ ) was used for calibration. The total tannin content in each sample was estimated by Broadhurst method. Extract solution $(0.4 \mathrm{~mL})$ was mixed with $3 \mathrm{~mL}$ of $4 \%$ vanillin and $1.5 \mathrm{~mL}$ of concentrated hydrochloric acid. The resultant mixture was incubated for 15 minutesin the incubator. Absorbance of the resulting blue solution was measured against reagent blank at $500 \mathrm{~nm}$ using spectrophotometer (KW UV-7504). The experiment was done in triplicate. Results were expressed as milligram of tannic acidequivalent (TAE) per gram of extract (TAE $\mathrm{mg} / \mathrm{g}$ dry extract). The concentrations of tannic acid equivalent (TAE) in the plant extracts were calculated by using the linear regressive equation from standard calibration curve of tannic acid. Total tannin contents in the plant sample were expressed as mg tannic acidequivalent per $1 \mathrm{~g}$ dry plant extract (TAE/mg).

(4) Determination of total phenolic contents of the samples by Folin-Ciocalteu method

The total phenol contents (TPCs) of the samples were determined UV-spectrometrically according to the FolinCiocalteu Method [13]. Firstly, $1 \mathrm{~mL}$ of different concentrations of gallic acid solution $(0.625,1.25,2.5,5,10 \mu \mathrm{g} / \mathrm{mL})$ was mixed with FCR solution $(1.5 \mathrm{~mL})$ and incubated at room temperature for 5 minutes. To each tube, $4 \mathrm{~mL}$ of $1 \mathrm{M}$ sodium carbonate solution was then added and the resultant mixture was allowed to stand for 2 hours at room temperature. Absorbance of the resulting blue solution was measured against reagent blank at $765 \mathrm{~nm}$ by using UV spectrophotometer (KWG UV-7504). All samples were measured in triplicate. A standard curve was constructed by plotting the absorbance against concentrations of gallic acid. This standard curve of gallic acid solutions (range from $0.625 \mu \mathrm{g} / \mathrm{mL}$ to $100 \mu \mathrm{g} / \mathrm{mL}$ ) was used for calibration. The total phenolic content in each sample was estimated by Folin-Ciocalteu method. Each extract $(20 \mathrm{mg})$ was mixed with $20 \mathrm{~mL}$ of distilled water. Each extract solution $(1 \mathrm{~mL})$ was mixed with $5 \mathrm{~mL}$ of FCR solution and incubated for 5 minutes. To each tube, $4 \mathrm{~mL}$ of $1 \mathrm{M}$ sodium carbonate solution was added and the tubes were kept at room temperature for 2 hours. The absorbance was measured at $765 \mathrm{~nm}$ spectrophotometrically (KWF UV-7504). The experiment was done in triplicate. Results were expressed as milligram of gallic acid equivalents (GAE) per gram of extract (mg GAE/ gdry extract). The concentration of gallic acid equivalent (GAE) of each of the plant extracts was calculated by using the linear regression equation from the standard curve of gallic acid. Total phenolic contents (TPCs) in the plant samples were expressed as mg gallic acid equivalent per gram dry plant extract (mg GAE/g of extract).

\subsection{Determination of Nutritional Constituents}

(1) Determination of carbohydrate content by anthrone method

The total carbohydrate content was estimated by the method of anthrone [15]. Carbohydrate is first hydrolyzed into 
simple sugars using dilute hydrochloric acid. In hot acidic medium glucose is dehydrated to hydroxymethyl furfural. This compound forms with anthrone a green coloured product with absorption maximum at $630 \mathrm{~nm}$. $0.4 \mathrm{~mL}$ of each of different concentrations of glucosesolution was mixed with $2.5 \mathrm{~mL}$ of anthrone reagent. The resultant mixture was stand for 10 minutes. Absorbance of the resulting dark green colour solution was measured at $630 \mathrm{~nm}$ by using UV spectrophotometer (KWG UV-7504). All samples were measured in triplicate. A standard curve was prepared by plotting the absorbance against concentrations of glucose. This standard curve of glucose solutions (range from $3.125 \mu \mathrm{g} / \mathrm{mL}$ to $25 \mu \mathrm{g} / \mathrm{mL}$ ) was used for calibration. The carbohydrate contents were determined by method of anthrone (Hedge and Hofreiter, 1962). The weight of $2.5 \mathrm{mg}$ of the sample powder was dissolved in $5.0 \mathrm{~mL}$ of $2.5 \mathrm{M} \mathrm{HCl}$ and cooled at room temperature. It was neutralized with $1 \mathrm{M}$ sodium carbonate and made up the volume to $100 \mathrm{~mL}$ and then centrifuged, collected the supernatant for analysis. The supernatant ( $5 \mathrm{~mL})$ was added to $2.5 \mathrm{~mL}$ of anthrone reagent and allowed to stand for $10 \mathrm{~min}$. The intensity of dark green colour developed was read at $630 \mathrm{~nm}$ by UV spectrophotometer. The blank solution was prepared as the above procedure by using distilled water instead of sample solution. The carbohydrate content was expressed as percentage based on the $100 \mathrm{~g}$ of sample powder.

\section{(2) Determination of moisture content}

The moisture contents of the samples were determined by oven drying method [16]. The moisture content was the weight lost due to the evaporation of water at the drying temperature. In this experiment, sample $(2 \mathrm{~g}$ each $)$ was placed in the three porcelain crucibles, which had previously been dried and cooled in air-tight desiccator, and accurately weighed. The porcelain crucibles with the samples were placed in an oven and dried for 30 minutes at $105{ }^{\circ} \mathrm{C}$. Then, they were removed from the oven and cooled in the air-tight desiccator at room temperature and weighed. The procedure was repeated until the loss in weight had not been changed. The moisture content was then calculated and the results are recorded.

\section{(3) Determination of ash content}

The ash content is the inorganic residue remaining after the organic matter has been burnt away [16]. Sample (2 g) was introduced into a predried and cooled porcelain crucible, and accurately weighed. Then, it was heated gently on an electronic stone until the sample was thoroughly charred. The crucible and content were then transferred to the Muffle furnace at $600^{\circ} \mathrm{C}$ for 2 hours until the residue was free from carbon. Then, the crucible containing residue was cooled in a desiccator and weighed. Heating, cooling and weighing were repeated until constant weight was obtained. The ash content of the sample was then calculated and the results obtained were recorded.

\section{(4) Determination of protein content}

The protein content of the kernel of star bean seeds was measured by Dumas method by using NDA 701 Dumas nitrogen analyser. The NDA 701 Dumas Nitrogen Analyzer gave the results that are produced in just 3 to 4 minutes per sample. The Dumas method starts with combustion to burn the sample, obtaining elemental compounds. The tin foil was used to calibrate and the EDTA was used as the standard. In this process, the water is removed by a first physical trap, positioned after the combustion, and a second chemical one. Between the two, the elemental substances passed through a reduction furnace. The auto-regenerative $\mathrm{CO} 2$ adsorbers let pass only the elemental nitrogen that is detected by the innovative Thermal Conductivity Detector (TCD). All the information will be constantly monitored from the main screen, including the real time graph.

\section{(5) Determination of fat content}

The fat content of the selected sample was determined by soxhlet extraction method. The plant sample (10 g) was placed in a cloth bag and it was then placed in a soxhlet extractor. Petroleum ether $\left(60-80{ }^{\circ} \mathrm{C}\right)$ was poured into the extractor until some of it over flowed in the flask. The flask was heated on a water bath. Extraction was assumed to be completed when a small amount of extract placed on a watch glass did not leave any residue on a evaporation of the solvent. Approximately 9 hours was required for the extraction to be completed, during which, the petroleum ether was recycled for about 27 times. After the extraction was completed, the petroleum ether was distilled off, the flask was dried at $100^{\circ} \mathrm{C}$ or in an oven to obtain constant weight. The difference in weight gave the amount of fat in the weight of plant sample taken.

\section{(6) Determination of dietary fibre content}

The fibre content of the selected sample was determined by acid-base digestion method. The defatted sample ( $2 \mathrm{~g})$ from Section 2.5.4 was placed into the $500 \mathrm{~mL}$ round-bottomed flask, the hot sulphuric acid solution (1.25\%) was added to the mark and the mixture was refluxed for about half an hour. The level constant was maintained by adding water periodically to prevent loss of solvent by evaporation. The solution was filtered through a fine piece muslin cloth into Buchner funnel. The residue was washed with distilled water until free from acid. The residue was transferred into the flask and $200 \mathrm{~mL}$ of hot sodium hydroxide solution $(1.25 \%)$ was added. The mixture was again refluxed for about half an hour and made the level constant by adding water at intervals. Then it was filtered through a 
Buchner funnel. The residue was washed with distilled water till the washing was neutral. It was finally washed with ethanol $(5 \mathrm{~mL})$ and petroleum ether $10 \mathrm{~mL}$. The fiber was transferred to a clean and dry crucible, dried at $100{ }^{\circ} \mathrm{C}$ to get constant weight.

\subsection{Investigation of Some Biological Properties}

(1) Determination of Antioxidant Activity of Ethanol and Watery Extracts

a) DPPH free radical scavenging assay

DPPH (2, 2- diphenyl-1-picryl hydrazyl) free radical scavenging assay was chosen to assess the antioxidant activity of the samples. This assay has been widely used to evaluate the free radical scavenging effectiveness of various flavonoids and polyphenols in food system. In this experiment, the antioxidant activity of ethanol and watery extracts of two selected plant samples was determined by DPPH free radical scavenging assay [13]. DPPH free radical scavenging activity was determined by UV-visible spectrophotometric method according to the procedure described by Kaur and Poonam (2014). The control solution was prepared by mixing $1.5 \mathrm{~mL}$ of $0.002 \%$ DPPH solution and 1.5 $\mathrm{mL}$ of ethanol in the brown bottle. The sample solution was also prepared by mixing $1.5 \mathrm{~mL}$ of $0.002 \% \mathrm{DPPH}$ solutions and $1.5 \mathrm{~mL}$ of test sample solution. These bottles were incubated at room temperature and were shaken on shaker for $30 \mathrm{~min}$. After 30 minutes, the absorbance of each solution was measured at $517 \mathrm{~nm}$ by using UV-visible spectrophotometer.

b) Ferric reducing assay

The ferric reducing antioxidant power was measured by using cyanoferrate method [17]. In this assay, Fe(III) reduction is often used as an indicator of electron donating activity, which is an important mechanism of phenolic antioxidant action. The reducing power of extracts was determined by using the cyanoferrate method. The different concentrations of $1 \mathrm{~mL}$ sample extracts and positive control solutions were mixed with $2.5 \mathrm{~mL}$ of phosphate buffer (pH 6.6) and $2.5 \mathrm{~mL}$ of $1 \%$ potassium ferricyanide. The mixture was incubated at $50{ }^{\circ} \mathrm{C}$ for 20 minutes. A portion $(2.5 \mathrm{~mL})$ of $10 \%$ trichloroacetic acid was added to the mixture to stop the reaction, which was then centrifuged at $3,000 \mathrm{rpm}$ for 10 minutes. $2.5 \mathrm{~mL}$ of upper layer solution was mixed with $2.5 \mathrm{~mL}$ of distilled water and $0.5 \mathrm{~mL}$ of $0.01 \% \mathrm{FeCl} 3$ solution and the absorbance measured at $700 \mathrm{~nm}$ were recorded. Each experiment was carried out at least three times and the data presented as an average of three independent determinations.

(2) Determination of Antidiabetic Activity of Ethanol and Watery Extracts

a) $\alpha$-amylase inhibitory activity

The $\alpha$-amylase inhibitory activity was determined using a modified assay of that described in the Worthington Enzyme Manual [18]. The enzyme inhibitory activity was expressed as a decrease in units of maltose liberated. A modified dinitrosalicylic acid (DNS) method was adopted to estimate the maltose equivalent. The tested samples (1 $\mathrm{mL}$ ) were pre-incubated with $1 \mathrm{~mL}$ of phosphate buffer and $2 \mathrm{~mL}$ of $\alpha$-amylase at $37{ }^{\circ} \mathrm{C}$ for 20 minutes and thereafter $0.4 \mathrm{~mL}(1 \% \mathrm{w} / \mathrm{v})$ starch solution was added. The mixture was further incubated at $37{ }^{\circ} \mathrm{C}$ for 30 minutes. Then the reaction was stopped by adding $2 \mathrm{~mL}$ of DNS reagent and the contents were heated in a boiling water bath for 10 minutes. A blank was prepared without plant extracts and another without the amylase enzyme, replaced by equal quantities of buffer. The absorbance was measured at $540 \mathrm{~nm}$. The reducing sugar released from starch was estimated as maltose equivalent from a standard graph. Acarbose was used as standard.

b) $\alpha$-glucosidase inhibitory activity

The $\alpha$-glucosidase inhibitory activity was determined using a modified assay of that described in the Worthington Enzyme Manual [18]. The $\alpha$-glucosidase inhibitory activity was measured the procedure described by McCue et al., (2005) [19]. The $\alpha$-glucosidase was assayed using $0.4 \mathrm{~mL}$ of sample extracts and $1 \mathrm{~mL}$ of $0.1 \mathrm{M}$ phosphate buffer (pH 6.9) containing $2 \mathrm{~mL}$ of $\alpha$-glucosidase solution, which was then incubated at $25{ }^{\circ} \mathrm{C}$ for 10 minutes. After the preincubation period, $0.5 \mathrm{~mL}$ of $0.005 \mathrm{M}$ p-nitrophenyl- $\alpha$-D-glucopyranoside solution was added to each well at timed intervals. The reaction mixtures were incubated at $25{ }^{\circ} \mathrm{C}$ for 5 minutes. After incubation, absorbance readings of the samples were recorded at $405 \mathrm{~nm}$ and compared with a control that had $0.4 \mathrm{~mL}$ of buffer solution in place of the extract. Acarbose was used as standard.

\section{(3) Determination of Cytotoxicity of Ethanol and Watery Extracts}

The ethanol and watery extracts were investigated by brine shrimp lethality bioassay according to the procedure described by Dockery and Tomkins, [20]. After aeration had been removed, the suspension was kept for 1 hour undisturbed, whereby the remaining unhatched eggs dropped. In order to get a higher density of larvae, one side of the separating funnel was covered with aluminium foil and the other illuminated with a lamp, whereby the phototropic larvae were gathering at the illuminated side and could be collected by pipette. The shrimp larvae were transferred to an agar well filled with $9 \mathrm{ml}$ of salt water and the dead larvae counted (number $\mathrm{N}$ ). A solution of crude extracts (31.25 
- $1000 \mathrm{ppm})(1 \mathrm{~mL})$ was added and the plate kept at room temperature in the dark. After 24 hours, the dead larvae were counted in each well under the microscope (number A). The still living larvae were killed by addition of ca. 0.5 $\mathrm{ml}$ methanol so that subsequently the total number of the animals could be determined (number $\mathrm{G}$ ). The mortality rate $\mathrm{M}$ was calculated in \%. Each test row was accompanied by a brine solution (number B). The mortality rate $\mathrm{M}$ was calculated using the following formula:

$\mathrm{M}=[(\mathrm{A}-\mathrm{B}-\mathrm{N}) /(\mathrm{G}-\mathrm{N})] \times 100$

Where:

M = Percent of the dead larvae after 24 hours

$A=$ Number of the dead larvae after 24 hours

$\mathrm{B}=$ Average number of the dead larvae in the brine solution after 24 hours

$\mathrm{N}=$ Number of the dead larvae before starting of the test.

$\mathrm{G}=$ Total number of brine shrimps

The control solution was prepared as the above procedure by using distilled water instead of sample solution.

(4) Screening of Antimicrobial Activities of the Ethanol and Watery Extracts

The antimicrobial activity of ethanol and watery crude extracts was determined against seven strains of microorganisms such as Bacillus subtilis, Staphylococcus aureus, Pseudomonas aeruginosa, Bacillus pumilus, Candida albicans, Escherichia coli and Agrobacterium tumefacines by employing agar well diffusion method [17]. In this assay, the crude extract $(0.5 \mathrm{~g})$, peptone $(0.5 \mathrm{~g})$ and sodium chloride $(0.25 \mathrm{~g})$ were mixed with distilled water and made up to $100 \mathrm{~mL}$ with distilled water. The $\mathrm{pH}$ of this solution was adjusted at 7.2 with $0.1 \mathrm{M}$ sodium hydroxide solution and $1.5 \mathrm{~g}$ of agar was added. Nutrient agar was prepared according to method described by Cruick (1975) [21]. Briefly nutrient agar was boiled and $20-25 \mathrm{~mL}$ of the medium was poured into a test tube and plugged with cotton wool and autoclaved at $121{ }^{\circ} \mathrm{C}$ for 15 minutes. Then the tubes were cooled down to $60{ }^{\circ} \mathrm{C}$ and poured into sterilized petri-dish and $0.1 \mathrm{~mL}$ of spore suspension was also added into the dishes. The agar was allowed to set for 30 minutes after which $10 \mathrm{~mm}$ plate agar well was made with the help of sterilized cork border. After that, about $0.1 \mathrm{~mL}$ of sample was introduced into the agar-well and incubated at $37^{\circ} \mathrm{C}$ for 24 hours. The inhibition zone (clear zone) appeared around the agar well indicating the presence of antimicrobial activity. The extent of antimicrobial activity was measured from the zone of inhibition diameter.

(5) Screening of antitumor activity by potato discs assay method (Potato Crown Gall Test)

The antitumor activity of ethanol and watery extracts was examined by Potato Crown Gall (PCG) or Potato Disc Assay (PDA) method [22] at the Fermentation Laboratory, Pharmaceutical Research Department, Ministry of Industry, Yangon, Myanmar.Tumor producing bacteria, Agrobacterium tumefacien, isolated from Sandoricum koetjape Merr. (Thitto) leaves were used in this study. In this assay, fresh disease-free potatoes were purchased from a local market. The surface of tubers of moderate size was sterilized by immersion in $0.1 \%$ sodium hypochlorite for 20 minutes. Ends were then removed and soaked for an additional 10 minutes. A core of the tissue was extracted from each and discarded. The remainder of the cylinder was cut into $1.0 \mathrm{~cm}$ thick discs with a surface sterilized scalpel. The discs were then transferred to agar plates $(1.5 \mathrm{~g}$ of agar dissolved in $100 \mathrm{~mL}$ deionized distilled water, autoclaved for 20 minutes at $121{ }^{\circ} \mathrm{C}, 20 \mathrm{~mL}$ poured into each Petri dish). Each plate contained three potato discs and 6 plates were used for each of the sample solution. Sample $(0.05,0.10,0.15 \mathrm{~g})$ was individually dissolved in DMSO (1 mL) and filtered through Millipore filters $(0.22 \mu \mathrm{m})$ into sterile tube. This solution $(0.5 \mathrm{~mL})$ was added to sterile distilled water $(1.5 \mathrm{~mL})$, and broth culture of A. tumefaciens in PBS $(2 \mathrm{~mL})$ was added. Controls were made in this way; DMSO $(0.5$ $\mathrm{mL})$ and sterile distilled water $(1.5 \mathrm{~mL})$ were added to the tube containing $2 \mathrm{~mL}$ of broth culture of A. tumefaciens. By using a sterile disposal pipette, 1 drop $(0.05 \mathrm{~mL})$ each from these tubes was used to inoculate each potato disc by spreading it over the disc surface. After inoculation, Petri dishes were sealed by film and incubated at $27 \sim 30{ }^{\circ} \mathrm{C}$ for 3 days. Observation was made on appearance of tumors on potato discs after 3 days under stero-microscope followed by staining with Lugol's iodine (10\% KI and5\% $\left.\mathrm{I}_{2}\right)$ after 30 minutes and compared with control. The antitumor activity was examined by observation of tumor produced or not on the potato discs.

(6) Determination of anti-inflammatory activity of ethanol and watery extracts by using CCK-8 Assay

Anti-inflammatory activity of the samples was evaluated by NO inhibition assay according to the method of Jin et al. [23] with some modifications. The RAW264.7 cells was cultured in $\alpha$-MEM supplemented with $10 \%$ heat incubated fetal bovine serum, and $1 \%$ penicillin $(10,000 \mathrm{U} / \mathrm{mL})$-streptomycin $(10 \mathrm{mg} / \mathrm{L})$. When the cell proliferation reaches about $70 \%$ confluency, the cells were harvested using cell scraper and diluted to a suspended in fresh medium. The $100 \mu \mathrm{L}$ of cells $\left(4 \times 10^{4} /\right.$ well $)$ were seeded in the 96 -well plates and incubated for $24 \mathrm{~h}$ at $37{ }^{\circ} \mathrm{C}$ in a humidified atmospheric containing $5 \% \mathrm{CO}_{2}$. The cells were then treated with $50 \mu \mathrm{L}$ each of LPS $(100 \mathrm{ng} / \mathrm{mL})$ and different doses 
of samples for $24 \mathrm{~h}$. NO production was monitored by measuring the accumulation of nitrite in the culture supernatant using Griess reagent [24]. In brief, $100 \mu \mathrm{L}$ each of the supernatant from 96-wells was mixed with equal volume of Griess reagent $\left(0.5 \%\right.$ sulfanilamide and $0.05 \%$ naphthylenediamide dihydrochloride in $\left.2.5 \% \mathrm{H}_{3} \mathrm{PO}_{4}\right)$ in the new 96 well plates and allowed to stand for $10 \mathrm{~min}$ at room temperature. The absorbance at $540 \mathrm{~nm}$ was measured using microplate reader. L-NMMA monoacetate was used as a positive control. On the other hand, the effect of the samples on the cell proliferation was evaluated by MTT methods. The remaining medium from the original plate was discarded and $100 \mathrm{uL}$ each of $10 \%$ MTT solution $(5 \mathrm{mg} / \mathrm{mL})$ in the medium was added. After $3 \mathrm{~h}$ incubation, the medium was discarded and $100 \mu \mathrm{L}$ each of DMSO was added to dissolve the formazan crystals and the absorbance at $570 \mathrm{~nm}$ was recorded by microplate reader. The percentage of NO inhibition and that of cell viability was calculated as follows:

NO inhibition $(\%)=\left[\left\{\mathrm{Abs}_{(\mathrm{control})}-\mathrm{Abs}_{\left(\text {sample }_{)}\right)} / \mathrm{Abs}_{(\mathrm{control})}\right\}\right] \times 100$, where $\mathrm{Abs}_{(\mathrm{control})}$ and $\mathrm{Abs}_{(\mathrm{blank})}$ are the absorbance of the control group treated by LPS alone and the absorbance of the samples

Cell viability $(\%)=100 \times\left[\left\{\mathrm{Abs}_{(\text {test samples })}-\mathrm{Abs}_{(\text {(blank })}\right\} /\left\{\operatorname{Abs}_{(\text {Control })}-\mathrm{Abs}_{(\text {(blank })}\right\}\right]$.

\subsection{Isolation of Lasiodiplodin from Chloroform Extract}

The crude chloroform extract (17.5 g) was applied on a column chromatography of Silica gel 70-230 mesh (169.5 g) and eluted with mixtures of petrol- $\mathrm{CHCl}_{3}, \mathrm{CHCl}_{3}-\mathrm{Me}_{2} \mathrm{CO}$ and $\mathrm{Me}_{2} \mathrm{CO}$. Isolated compounds from column chromatographic separation were detected by ${ }^{1} \mathrm{D}$ and ${ }^{2} \mathrm{D}$ Nuclear Magnetic Resonance spectral analysis $\left({ }^{1} \mathrm{H}\right.$ and ${ }^{13} \mathrm{C}$, DEPTs $90^{\circ}$ and $135^{\circ}$, COSY, HSQC, HMBC, NOESY) at ambient temperature in $\mathrm{CDCl}_{3}$ on a Bruker AMC instrument operating either at 300.13 for ${ }^{1} \mathrm{H}$ and $75.47 \mathrm{MHz}$ for ${ }^{13} \mathrm{C}$, NMR or $500.13 \mathrm{MHz}$ for ${ }^{1} \mathrm{H}$ and $125.77 \mathrm{MHz}$ for ${ }^{13} \mathrm{C}$, NMR based on the purification and quantity of respective compounds. Isolated compound was measured by high resolution mass spectra with a Waters Xevo Q ToF mass spectrometer coupled to a Waters Aquity UPLC system to deduce the total mass of isolated compounds. Infrared spectra of isolated compounds were recorded on an ATT Mattson Genesis Series FTIR ${ }^{\mathrm{TM}}$ using Win FIRST software to determine the functional groups of isolated compounds respectively.

\section{Results}

\subsection{Phytochemical Constituents of Stem Bark of Phyllanthus Albizzioides (Kurz) Hook. F.}

Preliminary phytochemical investigation was carried out to know the types of phytoorganic constituents present in selected sample. These results were summarized in Table 1.

Table 1. Phytochemical investigation of the stem barks of Phyllanthus albizzioides

\begin{tabular}{|c|c|c|c|c|c|}
\hline No & Test & Extract & Test Reagent & Observation & Remark \\
\hline \multirow{4}{*}{1} & \multirow{4}{*}{ Alkaloids } & \multirow{4}{*}{$1 \% \mathrm{HCl}$} & 1. Mayer's reagent & White ppt & + \\
\hline & & & 2. Dragendroff's reagent & Orangeppt & + \\
\hline & & & 3. Wagner's reagent & Reddishppt & + \\
\hline & & & 4. Sodium picrate & Yellowppt & + \\
\hline 2 & $\alpha$-amino acids & $\mathrm{H}_{2} \mathrm{O}$ & Ninhydrin Reagent & Purple spot & + \\
\hline 3 & Carbohydrates & $\mathrm{H}_{2} \mathrm{O}$ & $10 \% \alpha-N a p h t h o l+c o n c:$ S/A & Red ring & + \\
\hline 4 & Cyanogenic glycoside & $\mathrm{H}_{2} \mathrm{O}$ & Sodium picrate paper & No brick red colour & - \\
\hline 5 & Flavonoids & $\mathrm{EtOH}$ & $\mathrm{Mg}$ turning, $\mathrm{HCl}$ & Pink colour & + \\
\hline 6 & Glycosides & $\mathrm{H}_{2} \mathrm{O}$ & $10 \%$ lead acetate & White ppt & + \\
\hline 7 & Organic acid & $\mathrm{H}_{2} \mathrm{O}$ & Bromocresol green indicator & Brown colour & + \\
\hline 8 & Phenolic compounds & $\mathrm{H}_{2} \mathrm{O}$ & $1 \% \mathrm{FeCl}_{3}$ & Deep-blue colour & + \\
\hline 9 & Reducing sugars & $\mathrm{H}_{2} \mathrm{O}$ & Fehling's solution A and B & Brick-red ppt & + \\
\hline 10 & Saponins & & Distilled Water & Frothing & + \\
\hline 11 & Starch & $\mathrm{H}_{2} \mathrm{O}$ & Iodine solution & Deep blue colour & - \\
\hline 12 & Steroids & Toluene & Acetic anhydride and con. $\mathrm{H}_{2} \mathrm{SO}_{4}$ & Green colour & + \\
\hline 13 & Tannins & $\mathrm{H}_{2} \mathrm{O}$ & $1 \%$ Gelatin solution & White ppt & + \\
\hline 14 & Terpenoids & $\mathrm{CHCl}_{3}$ & Acetic anhydride and con. $\mathrm{H}_{2} \mathrm{SO}_{4}$ & Pink colour & + \\
\hline
\end{tabular}

According to these results, alkaloids, $\alpha$-amino acids, carbohydrates, flavonoids, glycosides, organic acids, phenolic compounds, reducing sugars, saponins, steroids, tannin and terpenoidswere found to be present in the stem bark of Phyllanthusalbizzioides. 


\subsection{Estimation of Phytoconstituents from Stem Barks of Phyllanthus Albizzioides}

Some phytocontituents of the stem barks of P.albizzioides were investigated under the recorded method. The total steroid contents were measured by employing Zak's methods and cholesterol was used as standard. The total flavonoid contents were determined by aluminium chloride methods and quercetin was used as standard. The total tannin contents were measured by Broadhurst Method. The total phenol contents were determined by using FolinCiocalteu reagent and standard gallic acid methods. The estimated phytoconstituents of the stem barks of Phyllanthus albizzioides was described in Table 2.

Table 2. Estimation of phytoconstituents from stem barks of Phyllanthus Albizzioides

\begin{tabular}{ccc}
\hline Phytoconstituents & Ethanol Extract & Water Extract \\
\hline Total Steroid Content $(\mathrm{mg} \mathrm{CE} / \mathrm{g})$ & $317.5 \pm 2.65$ & $236.25 \pm 1.77$ \\
Total Flavonoid Content $(\mathrm{mg} \mathrm{QE} / \mathrm{g})$ & $210 \pm 11.89$ & $99.09 \pm 2.41$ \\
Total Tannin Content $(\mathrm{mg} \mathrm{TAE} / \mathrm{g})$ & $110.1 \pm 6.8$ & $101.75 \pm 2.5$ \\
Total Phenol Content $(\mathrm{mg} \mathrm{GAE} / \mathrm{g})$ & $23.89 \pm 0.9$ & $20.05 \pm 1.6$ \\
\hline
\end{tabular}

\subsection{Estimation of Phytonutrients from Stem Barks of Phyllanthus Albizzioides}

Some phytontituents of the stem barks of P.albizzioides were investigated under the recorded method. The estimated phytonutrients of the stem barks of P.albizzioides was revealed in Table 3.

Table 3. Estimation of phytonutrients of stem barks of Phyllanthus Albizzioides

\begin{tabular}{ccc}
\hline Phytonutrients & Method & Composition (\%) \\
\hline Dietary Fiber & Acid-Base Digestion Method & $51.98 \%$ \\
Carbohydrate & Anthrone Method & $30.59 \%$ \\
Ash & Muffle Furnace Method & $7.45 \%$ \\
Moisture & Moisture Balance & $6.91 \%$ \\
Protein & Dumas Method & $2.45 \%$ \\
Fat & Soxhlet Extraction Method & $0.63 \%$ \\
\hline
\end{tabular}

\subsection{Investigation of Some Biological Properties}

(1) Antioxidant activities

There are several methods for screening of antioxidant activity of plant extracts. In this research, DPPH free radical scavenging assay and ferric reducing antioxidant power assay were used to screen the antioxidant activity of the ethanol and watery extracts of the selected sample. The results were described in Table 4.

Table 4. Antioxidant activities of ethanol and watery extracts of the stem barks of Phyllanthus Albizzioides

\begin{tabular}{ccc}
\hline \multirow{2}{*}{ Tested Sample } & \multicolumn{2}{c}{$\mathbf{I C}_{\mathbf{5 0}}(\boldsymbol{\mu g} / \mathbf{m L})$} \\
\cline { 2 - 3 } & DPPH assay & Ferric reducing assay \\
\hline Ethanol Extract & 16.03 & 36.91 \\
Watery Extract & 36.22 & 67.79 \\
*Standard & 0.75 (Gallic acid) & 2.71 (Quercetin) \\
\hline
\end{tabular}

\section{(2) Antidiabetic activities}

For antidiabetic activities, $\alpha$-amylase and $\alpha$-glucosidase inhibition assays were carried out. In these assays, the resulted data were reported in Table 5.

Table 5. Antidiabetic activities of ethanol and watery extracts of the stem barks of Phyllanthus Albizzioides

\begin{tabular}{ccc}
\hline \multirow{2}{*}{ Tested Sample } & \multicolumn{2}{c}{$\mathbf{I C}_{\mathbf{5 0}}(\boldsymbol{\mu g} \mathbf{m} \mathbf{m L})$} \\
\cline { 2 - 3 } & $\boldsymbol{\alpha}$-amylase inhibition & $\boldsymbol{\alpha}$-glucosidase inhibition \\
\hline Ethanol Extract & 21.48 & 15.35 \\
Watery Extract & 45.44 & 33.53 \\
*Standard acarbose & 0.016 & 0.042 \\
\hline
\end{tabular}


(3) Brine Shrimp Cytotoxicity Bioassay

The cytotoxicity of ethanol and watery extracts were evaluated by brine shrimp cytotoxicity bioassay. The resulted data were described in Table 6.

Table 6. 50\% Lethal dosage of ethanol and watery extracts of the stem barks of Phyllanthus Albizzioides

\begin{tabular}{cc}
\hline Sample & $\mathbf{L D}_{\mathbf{5 0}}(\boldsymbol{\mu g} / \mathbf{m L})$ \\
\hline Ethanol extract & 37.00 \\
Watery extract & 85.01 \\
$* \mathrm{~K}_{2} \mathrm{Cr}_{2} \mathrm{O}_{7}$ & 2.5 \\
$*$ Caffeine & $>1000$ \\
\hline
\end{tabular}

4) Antimicrobial activities of crude extracts by agar well diffusion method

The antimicrobial activity of ethanol and watery extracts obtained from the stem bark of P.albizzioides were determined against seven different strains of microorganisms by using agar well diffusion method. The inhibitions of seven microorganisms were shown in Figure 1 and the data were described in Table 7.

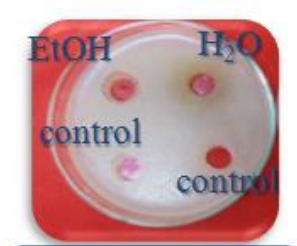

Bacillus subtilis

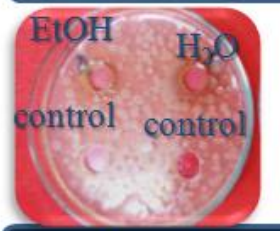

Candida albicans
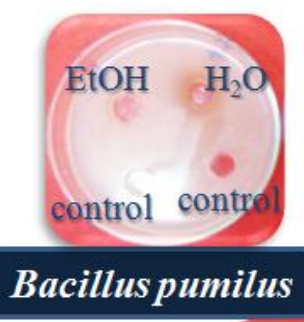

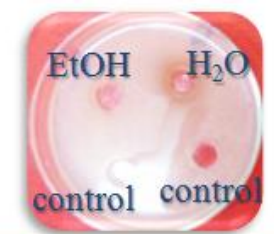

Staphlococcus aureus

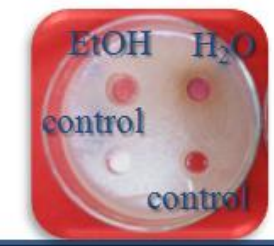

Pseudomonas auroginosa

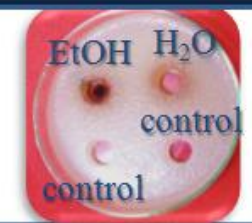

Agrobacterium tumerfaceins

Figure 1. Inhibition of ethanol and watery extracts of the stem barks of Phyllanthus albizzioides on seven microorganisms

Table 7. Antimicrobial activities of ethanol and watery extracts of the stem barks of Phyllanthus Albizzioides

\begin{tabular}{ccc}
\hline \multirow{2}{*}{ Microorganisms used } & \multicolumn{2}{c}{ Diameter of inhibition zone (mm) } \\
\cline { 2 - 3 } & EtOH & H2O \\
\hline (1) Bacillus subtilis & $16(++)$ & - \\
(2) Staphylococcus aureus & $16(++)$ & - \\
(3) Pseudomonas aeruginosa & $15(++)$ & - \\
(4) Bacillus pumilus & $15(++)$ & - \\
(5) Candida albicans & - & $14(+)$ \\
(6) Escherichia coli & $17(++)$ & $15(++)$ \\
(7) Agrobacterium tumefacines & $20(+++)$ &
\end{tabular}

Agar Well - $10 \mathrm{~mm}$

$\begin{array}{lll}10 \mathrm{~mm} \sim 14 \mathrm{~mm} & (+) & \text { low activity } \\ 15 \mathrm{~mm} \sim 19 \mathrm{~mm} & (++) & \text { higher activity } \\ 20 \mathrm{~mm} \sim \text { above } & (+++) & \text { highest activity }\end{array}$


(5) Antitumour Activity of Crude Extracts from Stem Bark of P. albizzioides

The antitumour activities were determined by crown gall method using three different concentrations of ethanol and watery extracts. The tumour inhibition of ethanol and watery extracts were observed in Figure 2.

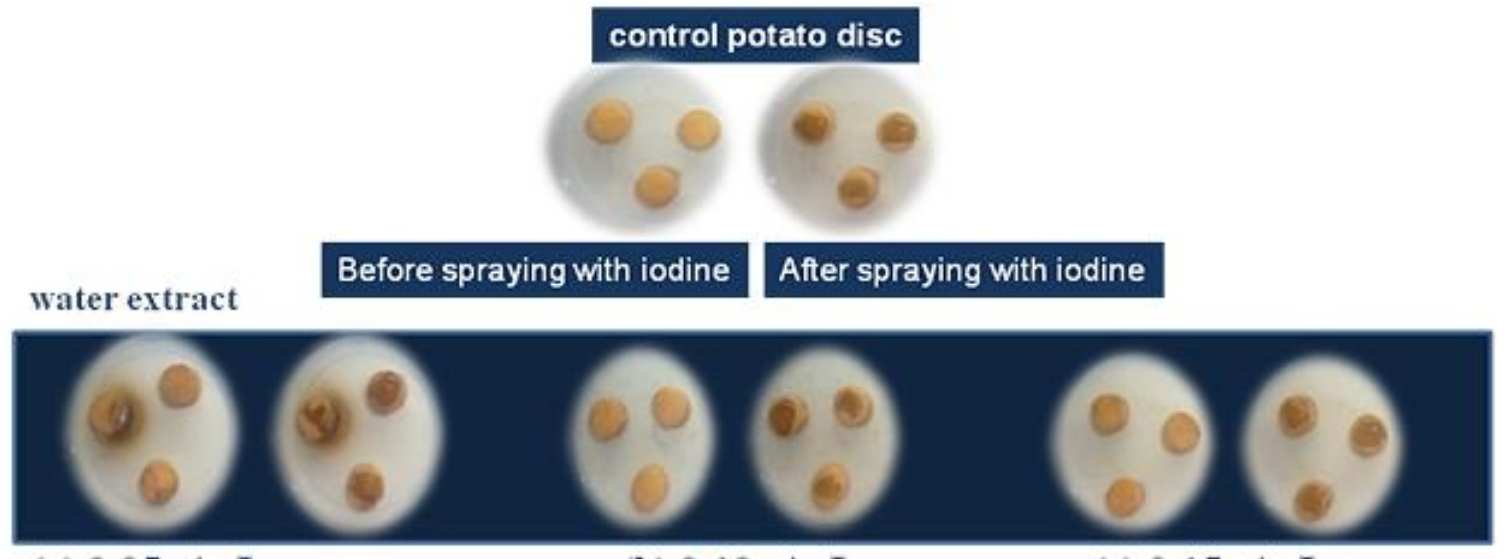

(a) $0.05 \mathrm{~g} / \mathrm{mL}$

(b) $0.10 \mathrm{~g} / \mathrm{mL}$

(c) $0.15 \mathrm{~g} / \mathrm{mL}$

\section{EtOH extract}

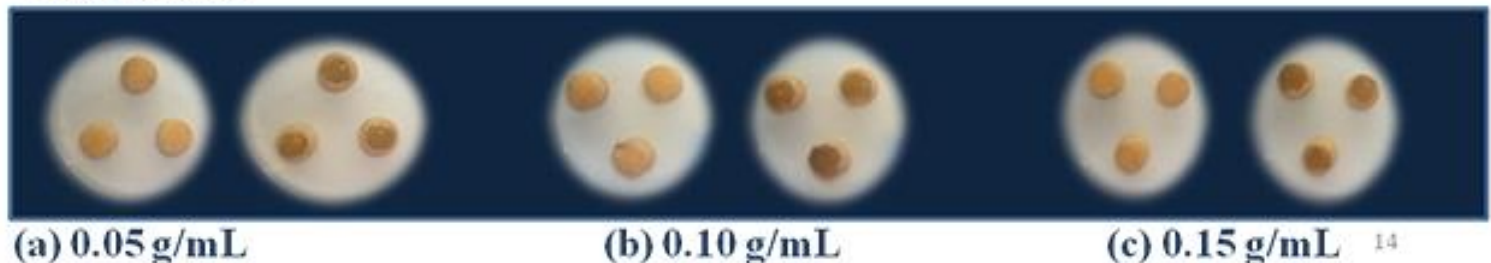

(a) $0.05 \mathrm{~g} / \mathrm{mL}$

(b) $0.10 \mathrm{~g} / \mathrm{mL}$

(c) $0.15 \mathrm{~g} / \mathrm{mL}$

Figure 2. Observation of tumor inhibition of ethanol and watery extract of stem bark of P.albizzioides

(6) Inhibition of NO production against LPS induced RAW264.7 cells

Anti-inflammatory activity of the samples was evaluated by nitric oxide (NO) inhibition assay using the RAW264.7 cells. The $\mathrm{IC}_{50}$ values of NO production against LPS induced RAW 264.7 cells were shown in Table 8.

Table 8. Inhibition of NO production against LPS induced RAW264.7 cells

\begin{tabular}{rc}
\hline Tested Sample & $\mathbf{I C}_{\mathbf{5 0}}(\mathbf{m g} / \mathbf{m L})$ \\
\hline Ethanol extract & 145.82 \\
Watery extract & 710.16 \\
*L-NMMA monoacetate & 98.25 \\
\hline
\end{tabular}

\subsection{Isolation of Lasiodiplodin from Chloroform Extract of P.albizzioides Stem Bark}

The isolated compound was as white solid, and its molecular formula $\mathrm{C}_{17} \mathrm{H}_{24} \mathrm{O}_{4}(0.0310 \mathrm{~g}, 0.18 \%$ yield $)$ was established on the basic of the (+)-HRESIMS m/z $293.1762[\mathrm{M}+\mathrm{H}]^{+}$, indicating 6 degree of unsaturation. The ${ }^{13} \mathrm{C}$ NMR, DEPT, ${ }^{1} \mathrm{H}$ NMR and HSQC spectra revealed the presence of five quaternary $\mathrm{sp}^{2}(\delta \mathrm{c} 168.48,158.66,157.80$, $142.53,116.88)$, one methine $\operatorname{sp}^{2}(\delta c 108.07)$, two methine $\operatorname{sp}^{3}$ ( $\left.\delta c 97.97,71.51\right)$, seven methylene $\mathrm{sp}^{3}(\delta \mathrm{c} 32.20$, $30.02,29.78,26.35,25.16,24.13,20.97)$, one methoxy $(\delta c 55.49)$ and one methyl $\mathrm{sp}^{3}(\delta c 19.25)$ carbons. The cross peak of H-2 $\left(\delta_{\mathrm{H}} 6.21\right)$ and $\mathrm{H}-4\left(\delta_{\mathrm{H}} 6.21\right)$ protons to $\mathrm{C}-3\left(\delta_{\mathrm{c}} 158.66\right), \mathrm{C}-5\left(\delta_{\mathrm{c}} 157.8\right)$ and C-6 ( $\left.\delta_{\mathrm{c}} 116.28\right)$ carbons revealed the substituted benzene ring. That the substituted benzene ring belonged to the methoxy was substituted by HMBC cross peak of $\mathrm{H}-16\left(\delta_{\mathrm{H}} 3.69, \mathrm{~s}\right)$ protons to $\mathrm{C}-5\left(\delta_{\mathrm{c}} 157.8\right)$ carbon. That another substituted of macrolactone ring was evidenced by the HMBC cross peaks of H-15 $\left(\delta_{\mathrm{H}} 2.4,2.6\right)$ to $\mathrm{C} 1\left(\delta_{\mathrm{c}} 142.53\right)$ as well as the COSY correlation of $\mathrm{H}-15-14\left(\delta_{\mathrm{H}} 2.4,2.6\right.$ and 1.57$), \mathrm{H}-14-13\left(\delta_{\mathrm{H}} 1.57\right.$ and 1.37$), \mathrm{H}-14-13\left(\delta_{\mathrm{H}} 1.57\right.$ and 1.18$), \mathrm{H}-12-13\left(\delta_{\mathrm{H}} 1.37\right.$ and 1.18$)$, H-8-9 $\left(\delta_{\mathrm{H}} 5.29\right.$ and $\left.1.55,1.85\right), \mathrm{H}-10-9\left(\delta_{\mathrm{H}} 1.6\right.$ and $\left.1.85,1.55\right)$. Then the methyl group was evidenced by the COSY correlation of H-8-17 $\left(\delta_{\mathrm{H}} 5.29\right.$ and 1.25$)$, the HMBC cross peak of H-17 $\left(\delta_{\mathrm{H}} 1.25, \mathrm{~d}, 6.45\right)$ to C-8 $\left(\delta_{\mathrm{c}} 71.51\right)$ described in Table 9. The isolated compound (3S)-12-Hydroxy-14-methoxy-3-methyl-3,4,5,6,7,8,9,10-octahydro-1H-2benzoxacyclododecin-1-one was identified by using the above spectral data and confirmed by physico-chemical determination (Table 10). 
Table 9. ${ }^{1} \mathrm{H}$ NMR, ${ }^{13} \mathrm{C}$ NMR (300.13 and $75 \mathrm{MHz}$ and $\left.\mathrm{CDCl}_{3}\right)$, DEPT and HMQC Correlation of Isolated Compound

\begin{tabular}{cccccc}
\hline No & Position & $\delta_{\mathrm{c}}$, type & $\delta_{\mathbf{H}},(\mathbf{J}$ in Hz $)$ & COSY & HMBC \\
\hline 1 & 7 & $168.48, \mathrm{C}=\mathrm{O}$ & --- & - & - \\
2 & 3 & $158.66, \mathrm{C}$ & -- & - & - \\
3 & 5 & $157.8, \mathrm{C}$ & --- & - & - \\
4 & 1 & $142.53, \mathrm{C}$ & --- & - & - \\
5 & 6 & $116.88, \mathrm{C}$ & --- & - & $\mathrm{C}-3, \mathrm{C}-5, \mathrm{C}-6$ \\
6 & 2 & $108.07, \mathrm{CH}$ & $6.21, \mathrm{~s}$ & $\mathrm{C}-3$ \\
7 & 4 & $96.97, \mathrm{CH}$ & $6.21, \mathrm{~s}$ & - \\
8 & 8 & $71.51, \mathrm{OCH}$ & $5.29, \mathrm{ddd}(3.11,6.47,9.65)$ & $\mathrm{H}-17, \mathrm{H}-9$ & $\mathrm{C}-5$ \\
9 & 16 & $55.49, \mathrm{OCH}_{3}$ & $3.69, \mathrm{~s}$ & - & - \\
10 & 9 & $32.2, \mathrm{CH}_{2}$ & $1.85,1.55, \mathrm{~m}$ & $\mathrm{H}-15, \mathrm{H}-14$ & $\mathrm{C}-1, \mathrm{C}-14, \mathrm{C}-6, \mathrm{C}-2$ \\
11 & 15 & $30.02, \mathrm{CH}_{2}$ & $2.4, \mathrm{dd}(6.63,13.26) 2.6, \mathrm{dd}(7.86,13.44)$ & - & - \\
12 & 14 & $29.78, \mathrm{CH}_{2}$ & $1.57, \mathrm{~m}$ & - & - \\
13 & 11 & $26.35, \mathrm{CH}_{2}$ & $1.36, \mathrm{~m}$ & $\mathrm{H}-10$ & - \\
14 & 13 & $25.16, \mathrm{CH}_{2}$ & $1.18, \mathrm{~m}$ & - & - \\
15 & 12 & $24.13, \mathrm{CH}_{2}$ & $1.37, \mathrm{~m}$ & $\mathrm{H}-12$ & - \\
16 & 10 & $20.97, \mathrm{CH}_{2}$ & $1.35,1.6, \mathrm{~m}$ & - & $\mathrm{C}-8, \mathrm{C}-9$ \\
\hline
\end{tabular}

Table 10. Physico-chemical Properties of Isolated Compound

\begin{tabular}{ccc}
\hline Experiment & Observation & Remark \\
\hline UV $(254 \mathrm{~nm})$ & Active & Present of conjugated double bonds \\
$10 \% \mathrm{KMnO}_{4}$ & Colour discharge & $\mathrm{C}=\mathrm{C}$ present \\
$2,4-\mathrm{DNP}$ & Yellow ppt & $\mathrm{C}=$ O present \\
Dragendroff's & No ppt & not alkaloid \\
$\mathrm{HCl}, \mathrm{Mg}$ turnings $_{10 \% \mathrm{FeCl}_{3}}$ & No colour change & Not Flavonoid \\
$10 \%$ lead acetate & Blue colour & Phenolic compound \\
\hline
\end{tabular}

\section{Discussion}

The stem barks of $P$. albizzioides is very rich in chemical constituents but not to be found the cyanogenic glycoside which is toxic to consume. The chemical constituents in ethanol extract of the stem barks of $P$. albizzioides were found to be rich comparing with watery extracts. The total steroid contents were observed to be highest in ethanol extract. The second and third highest chemical constituents were found to be the flavonoid and tannin compounds. Flavonoid and tannin compounds can prevent the development of bacteria and can be converted to inactive substances. Among the nutritional constituents, the fiber content was observed in highest amount. Fiber is a type of carbohydrate that the body cannot digest. Fiber helps to regulate the body's use of sugars, helping to keep hunger and blood sugar in check. There are several methods for screening of antioxidant activity of plant extracts. In this research, DPPH free radical scavenging assay and ferric reducing antioxidant power assay were used to screen the antioxidant activity of the ethanol and watery extracts of the selected sample. From the observation of these results, the ethanol extracts possess the higher activities than watery extracts but weaker than the potency of standard compounds. For antidiabetic activities, $\alpha$-amylase and $\alpha$-glucosidase inhibition assays were carried out. In that case, ethanol extracts were found to be higher activities than the watery extracts in both assays. The cytotoxicity of ethanol and watery extracts were evaluated by brine shrimp cytotoxicity bioassay. From this experimental data, the cytotoxicity of the ethanol extract of the selected sample was more toxic to brine shrimp than the watery extract. The antimicrobial activity of ethanol and watery extracts obtained from the stem bark of P.albizzioides were determined against seven different strains of microorganisms by using agar well diffusion method. From the observation of these results, the ethanol extract was exhibited highest antimicrobial activities against Agrobacterium tumefacines and medium activities against $B$. subtilis, B. pumilus, $S$. aureus, $P$. aeruginosa and E. coli. The watery extract was showed against only two microorganism $E$ coli and Agrobacterium tumefacines. The antitumor activity were determined by crown gall method using three different concentrations of ethanol and watery extracts. Tumor inhibition was significantly observed at all 
concentration for each extracts. Anti-inflammatory activity of the samples was evaluated by nitric oxide (NO) inhibition assay using the RAW264.7 cells. According to these data, the ethanol extract of stems showed the distinct higher activities than the watery extract. By silica gel column chromatographic separation, lasiodiplodin (0.0310 g) was isolated. Yield \% is $0.18 \%$. From the spectroscopic data, the isolated compound is lasiodiplodin. The structure of lasiodiplodin compound was shown with COSY correlation as the bold line and HMBC correlation as the arrow line.

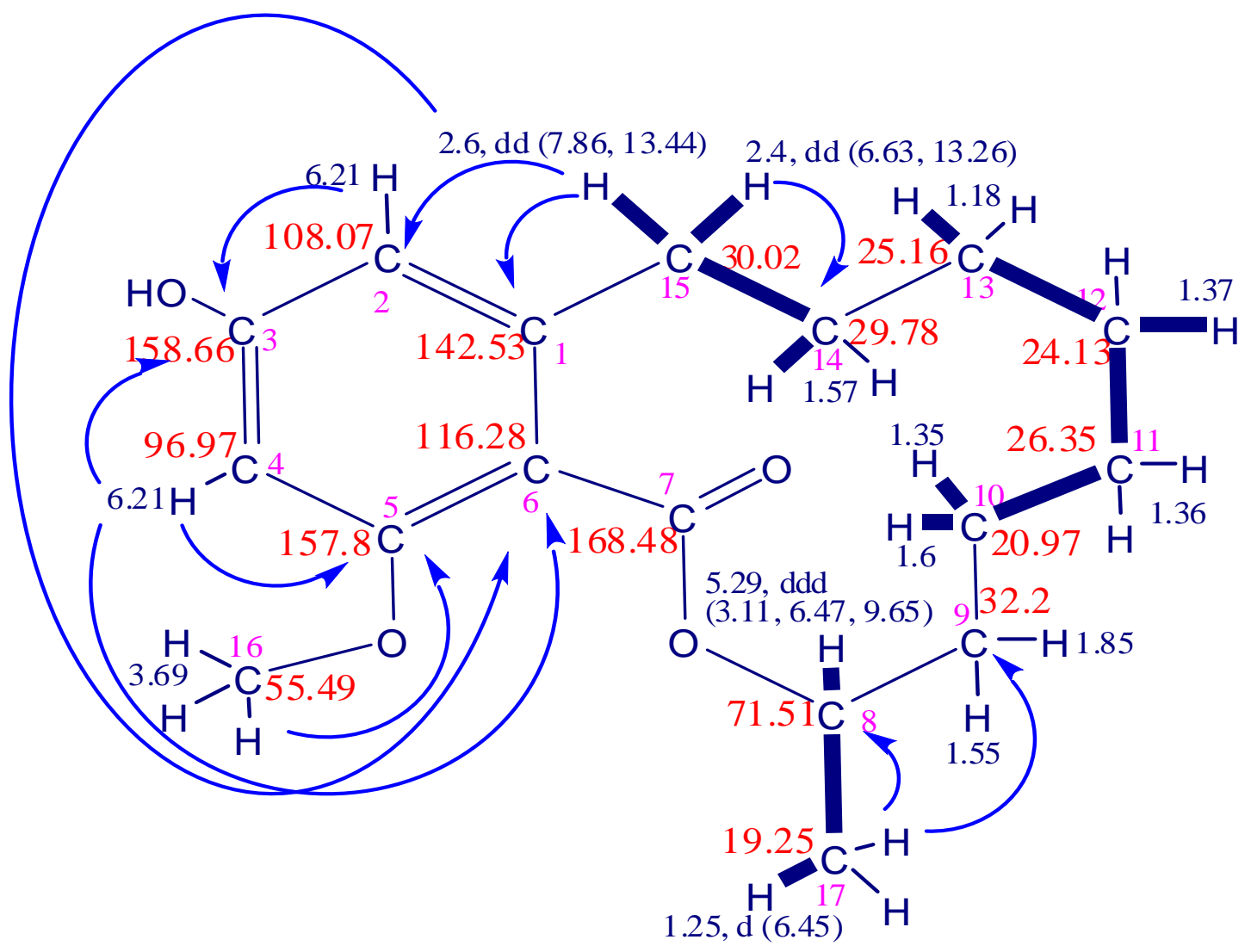

Figure 3. The structure of lasiodiplodin compound

\section{Conclusion}

The main goals of this study, ideally aimed to investigate the screening of phytochemicals and some biological activities of Phyllanthus albizzioides. The ethanol extract of stem bark showed the distinct higher activities such as antioxidant, antidiabetic, antimicrobial, cytotoxicity, antitumor and NO inhibition activity than the watery extract. Furthermore, Lasiodiplodin was observed as a major constituent in the stem barks. Several studies have reported that Lasiodiplodin have antibiological activities such as anticancer, antibacterial, antifungal, antileukemic and cytotoxicity. Therefore, the present study will contribute that the stem barks of $P$. albizzioides can be used as traditional medicine to treat many diseases.

\section{Declaration of Competing Interest}

The authors declare that they have no known competing financial interests or personal relationships that could have appeared to influence the work reported in this paper.

\section{Ethical Approval}

All procedures performed in studies involving human participants were in accordance with the ethical standards of the institutional and/or national research committee and with the 1964 Helsinki declaration and its later amendments or comparable ethical standards.

\section{References}

[1] Thomas, E., Vandebroek, I., Sanca, S. \& Van Damme, P. (2009).Cultural significance of medicinal plant families and species among Quechua farmers in Apillapampa, Bolivia, J. Ethnopharmacol, 122(1), 60-67. doi: 10.1016/j.jep.2008.11.021.

[2] Harborne, J. B. (1984). The Organic Constituents of Higher Plant: Their Chemistry and Interrelationships. 4th Ed., Cordus Press, North Amherst, 58. 
[3] Salim, A. A., Chin, Y. W. \& Kihhorn, A. D. (2008). Drug Discovery from Plants. Bioactive Molecules and Medicinal Plants, 978-3-540-74603-4-1, OSpringer, 1-25

[4] Mukerjee, P. K., Saritha, G. S. \& Suresh, B. (2002). Antimicrobial potential of two different Hypericum species available in India. Phytotherapy Research, 16(7), 692-695. https://doi.org/10.1002/ptr.1016.

[5] Ghani, A. (1998). Medicinal Plants of Bangladesh. 1st Ed., Asiatic Society of Bangladesh, Dhaka., 9-11.

[6] Trease, G. E. \& Evans. W. C. (1980). Pharmacognosy. London: Spottis Woode Ballantyne, 622. https://doi.org/10.1002/jps.2600690550.

[7] Robinson, T. (1983).The Organic Constituents of Higher Plants: Their Chemistry and Interrelationships. North America: 5th Ed., Cordus Press, 63-68.

[8] M-Tin Wa. (1970). Phytochemical Screening Methods and Procedure. Phytochemical Bulletin of Botanical Society of America Inc., 5(3), 4-10.

[9] Vogel, A. I. (1966). A Text Book of Practical Organic Chemistry. London: 3rd Ed., English Language Book and Longman Group Ltd., 453

[10] Finar, I. L. (1909).Organic Chemistry.London:Longmans Greens and Co. Ltd., III. 304-305.

[11] Marini-Bettolo, G. B., Nicole, H. M. \& Palamia. M. (1981). Plant Screening by Chemical and Chromatographic Procedure under Field Conditions. J. Chromatog., 213, $121-123$.

[12] Zak, B., Dickenman, R. C., White, E. G., Burnett, H. \& Cherney, P. J. (1981). Rapid estimation of free and total cholesterol. Life Sciences, 24(18): 16.

[13] Basma, A. A., Zakaria, Z., Latha, L. Y. \& Sasidharan, S. (2011). Antioxidant Activity and Phytochemical Screening of the Method Extracts of Euphorbia hirta L. Asia Pacific Journal of Tropical Medicine, 8 (8), 386 - 390.

[14] Broadhurst, R. B. \& Jones, W. T. (1978). Analysis of Condensed Tannins Using Acidified Vanillin. J. Sci. Food Agr.,29, $788-$ 794.

[15] Hedge, J. E. \& Hofreiter, B. T. (1962). Methods in Carbohydrate Chemistry. (Eds.,) Whistler, R. L. and BeMiller, J. N., New York: Academic Press, 17, 420.

[16] A.O.A.C. (2000).Official and Tentative Methods of Analysis, Association of Official Analytical Chemists, USA: 17th Ed., Gaithersburg, Maryland, AOAC International, 63-67.

[17] Kaur, S. \& Poonam, M. (2014). Study of Total Phenolic and Flavonoid Content, Antioxidant Activity and Antimicrobial Properties of Medicinal Plants. Journal of Microbiology and Experimentation, 1(1), 1-6.

[18] Kwon, Y. I., Vattem, D.V. \& Shetty, K. (2006). Evaluation of clonal herbs of Lamiaceae species for management of diabetes and hypertension. Asia Pac. J. Clin. Nutr.15, 107-118.

[19] McCue, P., Kwon, Y. I. \& Shetty, K. (2005). Anti-amylase, anti-glucosidase and anti angiotensin I converting enzyme potential of selected foods, J Food Biochem. 29, 278-294.

[20] Dockery, M. \& Tomkins, S. (2000). Brine Shrimp Ecology. 1st Ed., The British Ecology Society, London, 92-93.

[21] Cruick, R. (1975). Medicinal Microbiology. London: 11th Ed, E \& S Living Stone, 234 - 241.

[22] Coker, P. S., Radecke, J. Guy, C. \& Camper, N. D. (2005). Potato Disc Tumor Induction Assay: A Multiple Mode of Drug Action Assay. J of Phytomedicine, 10, 133-138.

[23] Jin, S. E.; Son, Y. K.; Min, B. S.; Jung, H. A. \& Choi, J. S. (2012). Anti-inflammatory and Antioxidant Activities of Constituents Isolated from Pueraria lobata Roots, Arch. Pharm. Res. 35, 823 $\square 33$. DOI 10.1007/s12272-012-0508-x.

[24] Schmidt, H. \& Kelm, M. (1996). Determination of nitrite and nitrate by the Griess reaction. In: Feelisch, M.; Stamler, J.; Eds, Methods in Nitric Oxide Research. John Wiley \& Sons, Chichester (UK), 491-497. 


\section{Appendix I}

AKPA 164-166/6-15 (10-30)

Figure A1. HRESIMS spectrum of isolated compound
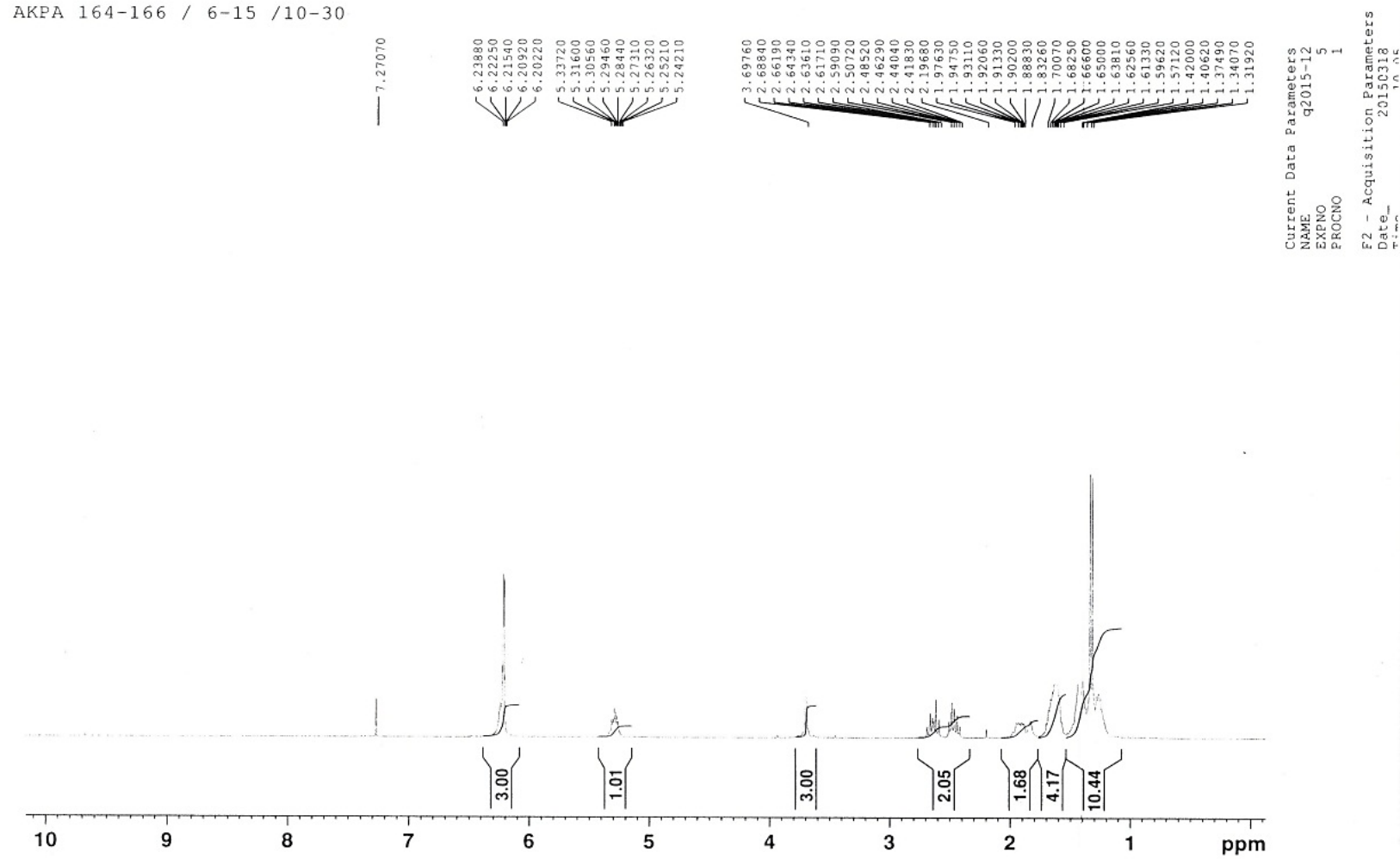

Figure A2. ${ }^{1} \mathrm{H}$ NMR spectrum of isolated compound 

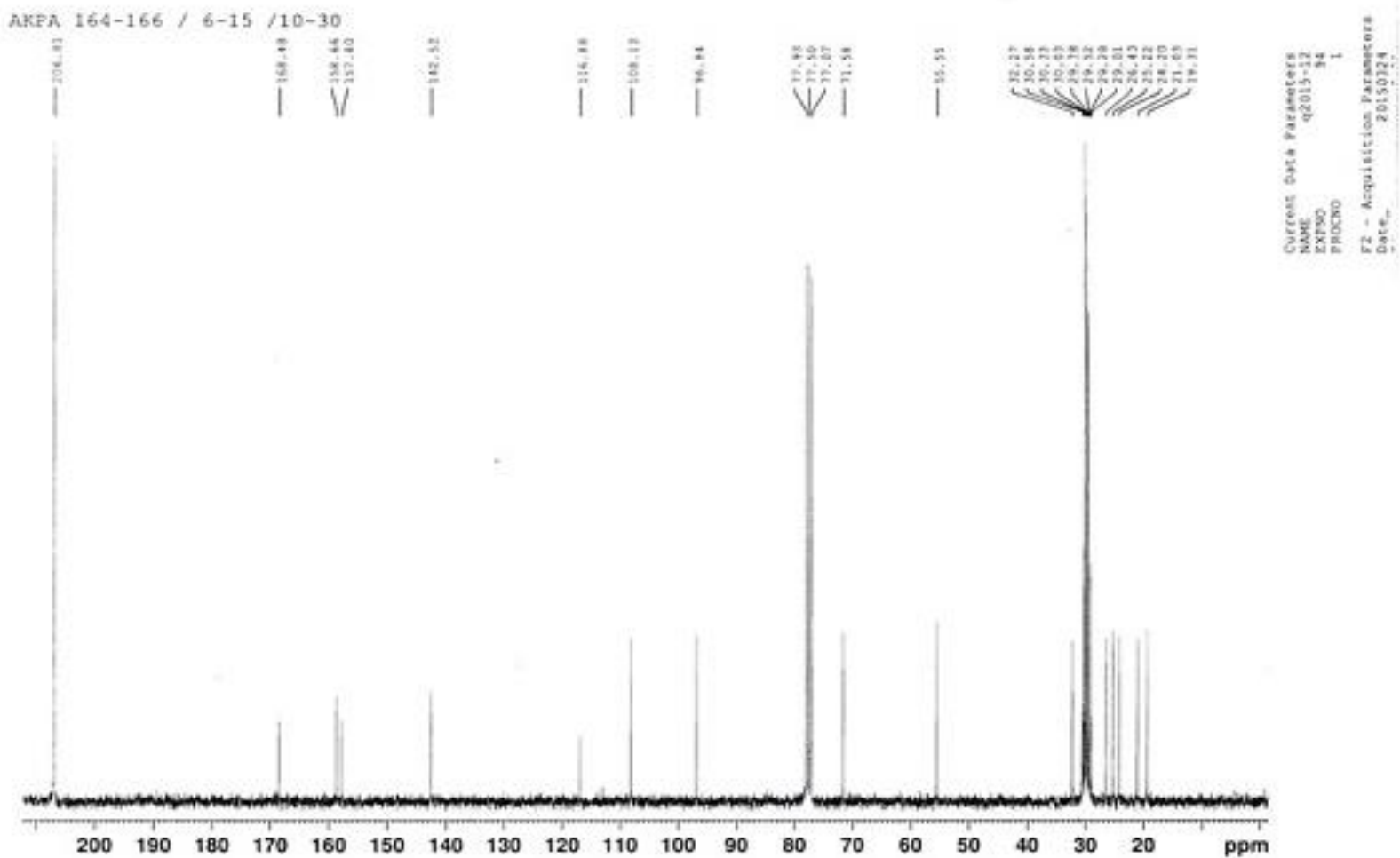

Figure A3. ${ }^{13} \mathrm{C}$ NMR spectrum of isolated compound

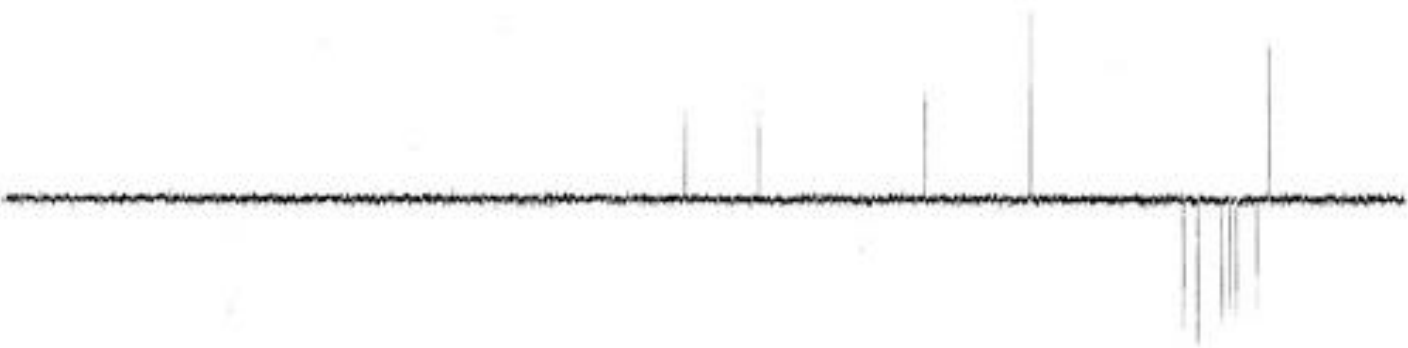

$\begin{array}{llllllllllllllllllll}200 & 190 & 180 & 170 & 160 & 150 & 140 & 130 & 120 & 110 & 100 & 90 & 80 & 70 & 60 & 50 & 40 & 30 & 20 & \mathrm{ppm}\end{array}$

Figure A4. DEPT spectrum of isolated compound 


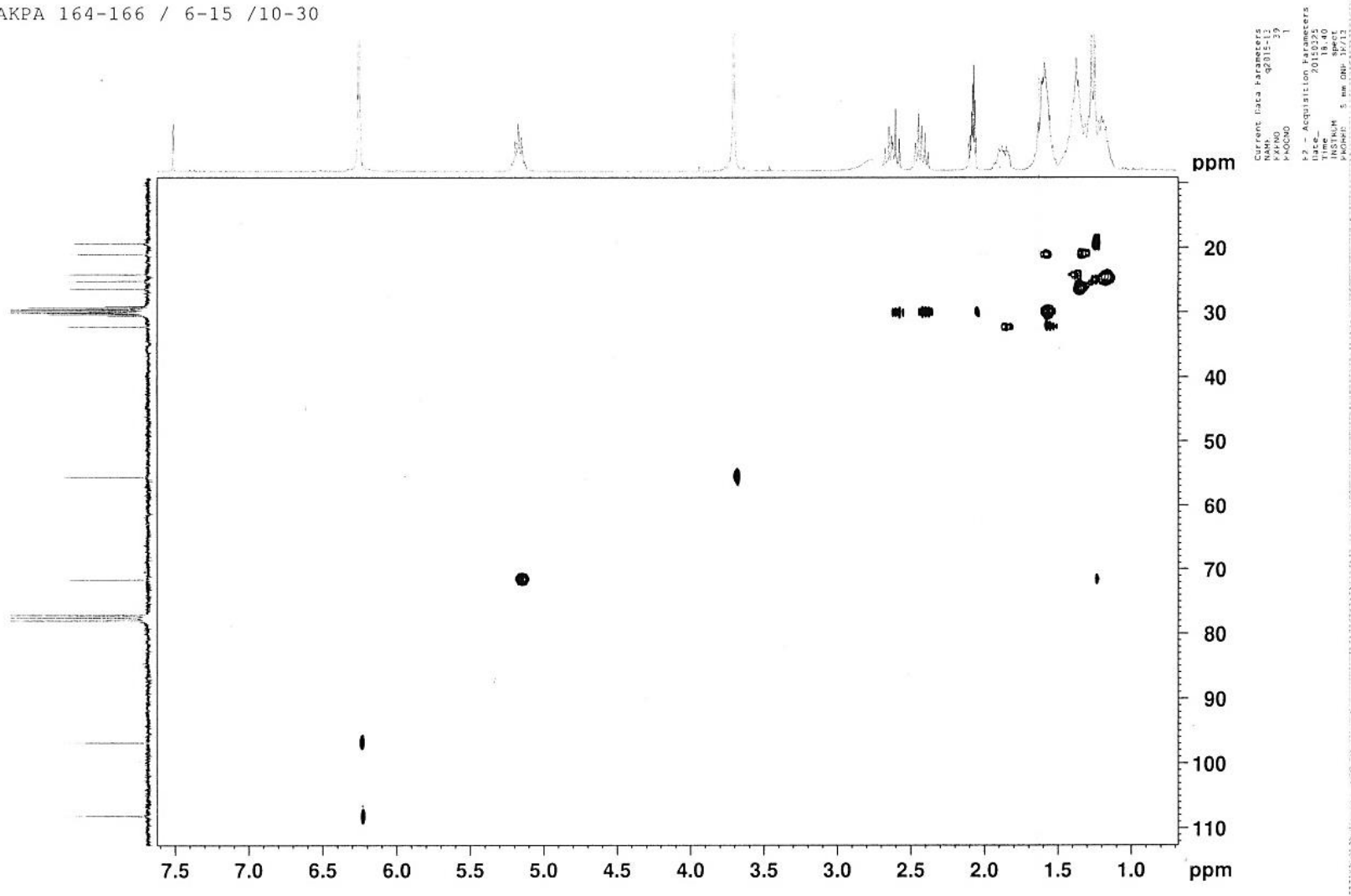

Figure A5. HMQC spectrum of isolated compound

AKPA $164-166 / 6-15 / 10-30$

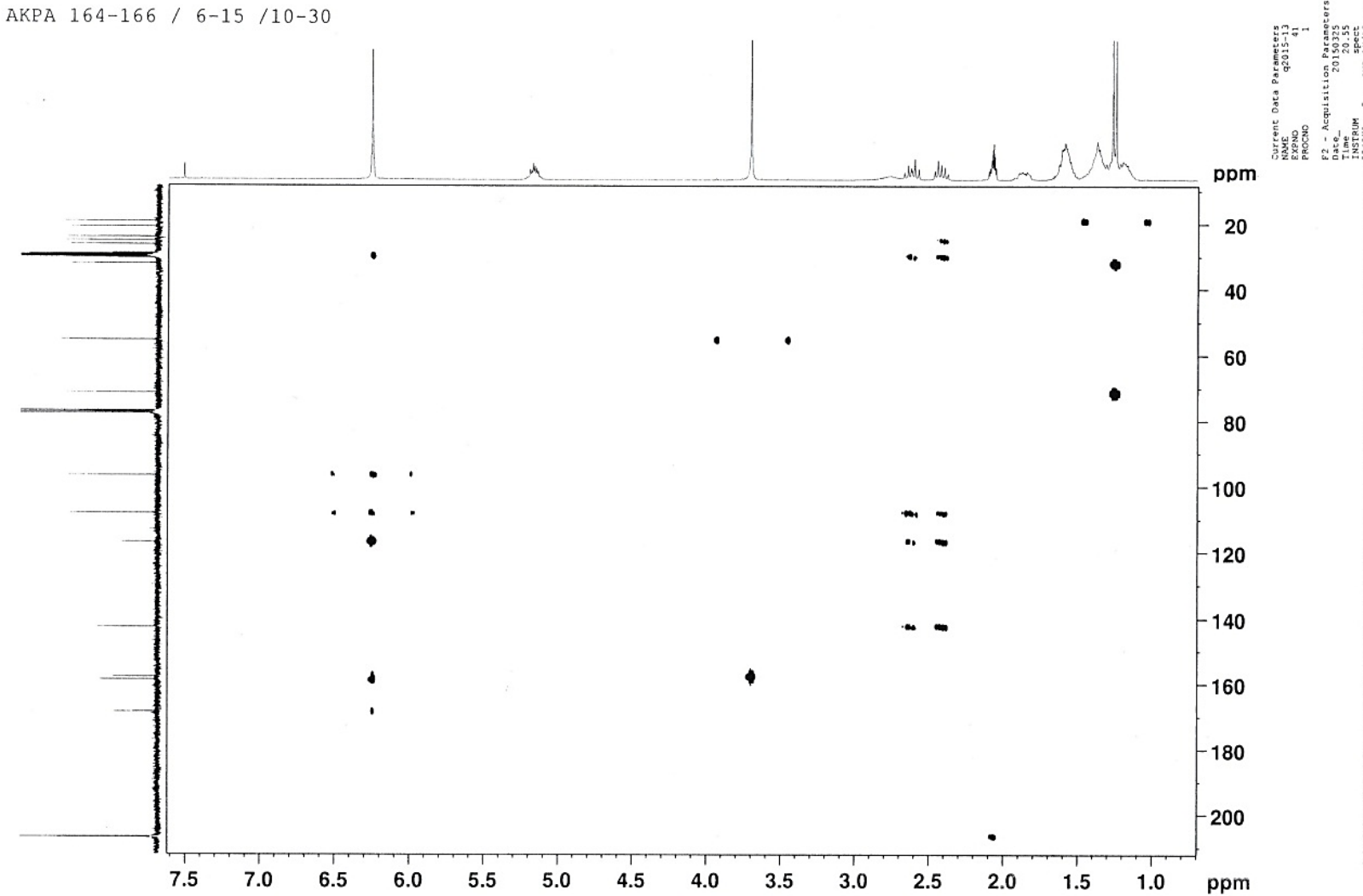

Figure A6. HMBC spectrum of isolated compound 


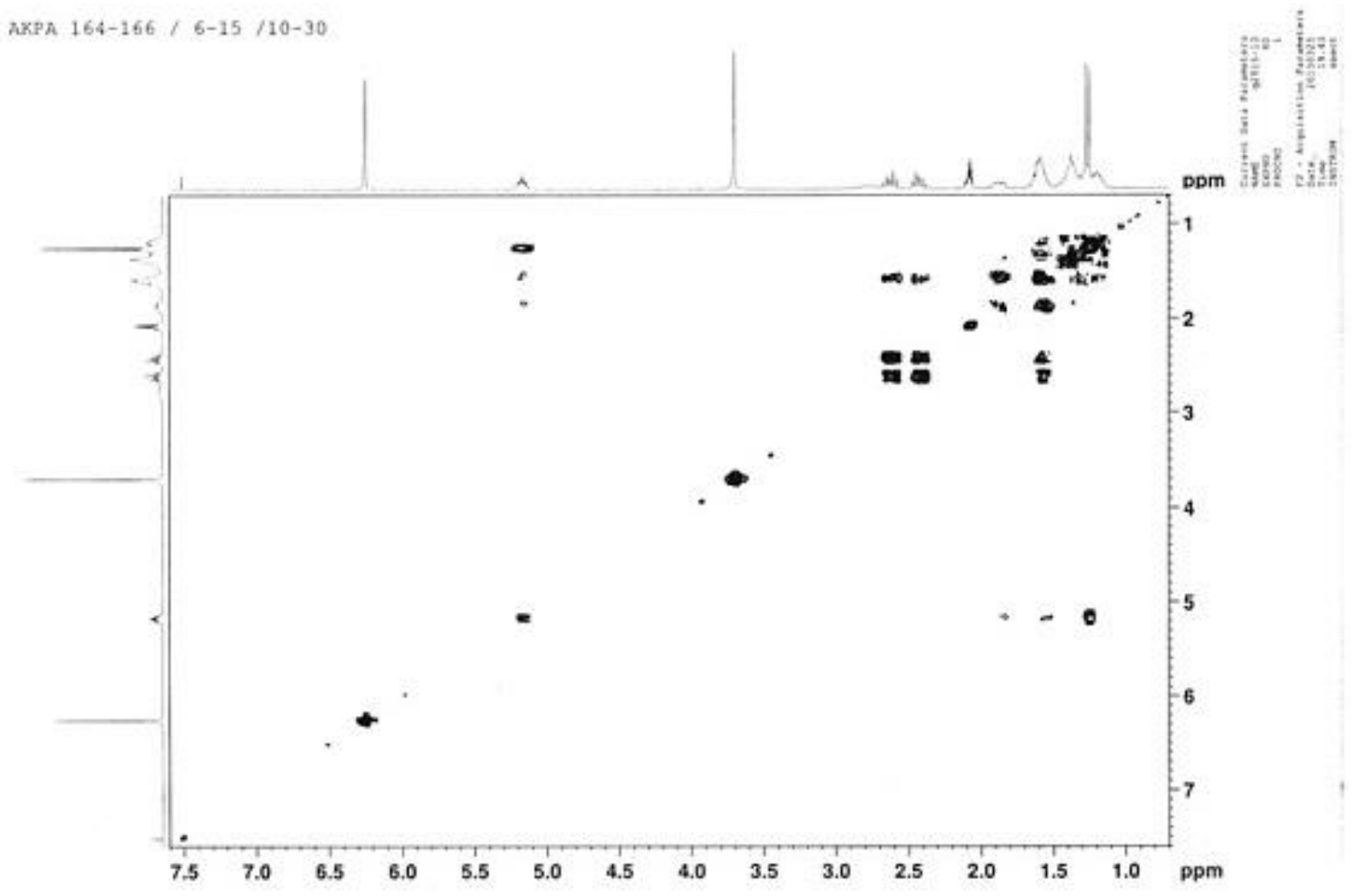

Figure A7. COSY spectrum of isolated compound 